\title{
Tensar las fibras: conflicto y negociación en la construcción de identidades
}

\section{Fibers under tension: conflict and negotiation in the construction of identities}

\author{
Sara M. López Campeny ${ }^{1,2}$ y Carolina Agüero ${ }^{3}$
}

La historia de este volumen temático se inicia en el año 2015, cuando entre los días 12 y 17 de julio se llevó a cabo en la ciudad de San Salvador, en El Salvador, el 55 Congreso Internacional de Americanistas, bajo la consigna "Conflicto, paz y construcción de identidades en las Américas”. En el marco de dicho encuentro, las editoras de este volumen convocamos a un simposio temático que, en sintonía con el lema del congreso, se titulaba "Tensar las fibras: conflicto y negociación en la construcción de identidades. Miradas desde la evidencia textil en América”.

Nos propusimos entonces generar un espacio de diálogo y reflexión que nucleara a ponentes interesados en compartir la discusión de aspectos teóricos, metodológicos y analíticos, relacionados con estos ejes centrales: conflicto, negociación e identidades; atravesados por el estudio de diversas evidencias textiles - tanto directas como indirectas- producidas y/o usadas por diferentes poblaciones de las Américas.

Partimos de una concepción holística e integradora, que entiende la producción textil como un proceso dinámico que involucra un conjunto de conocimientos, pericias, técnicas, gestos, instrumental y recursos varios y que se inicia desde el manejo, cuidado, cultivo y/o recolección de la materia prima. En cuanto a los testimonios directos, consideramos que "lo textil" involucra desde las primeras acciones de manipulación y selección de las fibras hasta su transformación en un producto cultural. En cuanto a las evidencias indirectas, el instrumental asociado a la producción textil, las impresiones textiles conservadas sobre distintas superficies y las imágenes plasmadas en variados soportes (cerámica, arte rupestre, escultórica, códices, entre otros) conservan información que -en condiciones ambientales menos favorables para la conservación orgánica- se hubiera perdido inevitablemente con los textiles originales, por lo que constituyen también testimonios sumamente relevantes para el estudio de esta temática. Todos estos planos de la evidencia textil fueron contemplados en la convocatoria.

1 Instituto de Arqueología y Museo (IAM), Universidad Nacional de Tucumán, ARGENTINA. Email: marisalopezc@hotmail.com

2 Instituto Superior de Estudios Sociales (ISES), Consejo Nacional de Investigaciones Científicas y Técnicas (CONICET), ARGENTINA.

3 Instituto de Investigaciones Arqueológicas y Museo (IIAM), Universidad Católica del Norte, CHILE.Email: maguero@ucn.cl 
A inicios del siguiente año, y gracias al espacio editorial brindado por Estudios Atacameños. Arqueología y Antropología Surandinas, invitamos a las y los participantes del simposio, que en esa ocasión presentaron diversas experiencias y casos de estudio, a enviar sus ponencias para ser consideradas en el presente volumen.

Y así, por una parte, podemos decir que el conjunto de trabajos que finalmente integran este dossier muestra una valiosa diversidad en distintos aspectos, tales como:

a. La dimensión temporal: que abarca el estudio de diferentes manifestaciones desde momentos prehispánicos hasta casos de estudio desplegados en contextos de producción actuales; incluyendo en este continuum temporal también ejemplos que remiten al período colonial temprano y a los dos últimos siglos pasados (XIX y XX).

b. La dimensión espacial: en este plano las comunidades y casos de estudio abordados nos trasladan desde el actual territorio de México, pasando por varias regiones y paisajes culturales de los Andes meridionales, luego las diversas áreas del noreste y centro de Argentina (actuales provincias de Santiago del Estero, Córdoba y San Juan), hasta el llamado "Chaco paraguayo".

c. La dimensión material: aquí confluyen, de forma variada, aproximaciones a la materialidad textil a partir del estudio de distintos soportes, tanto directos como indirectos. Entre los primeros se analizan prendas elaboradas con técnicas y materiales diversos (telares, arte plumario, bordados, ornamentaciones de distintos tipos, entre otros) y que conllevan diferentes usos, funciones primarias y complejas implicancias socioculturales. $\mathrm{Y}$, en lo que respecta a las evidencias indirectas, se incluyen en el presente volumen casos de análisis de representaciones que aluden al "universo textil" desde la consideración de distintos soportes: rupestre, códices, esculturas, fotografías y hasta el propio cuerpo humano.

d. Todos estos planos de multiplicidad resultan en aproximaciones que ponen en práctica metodologías de análisis plurales, que conjugan miradas desde una perspectiva arqueológica, antropológica, etnográfica, museográfica y/o documental, las que son aplicadas al estudio tanto de fuentes recuperadas primariamente por los propios autores como de otras, resultado de una valiosa pesquisa y "rescate" de materiales que actualmente integran distintas colecciones museográficas.

Pero, por otra parte, nos parece que es posible identificar ciertas líneas directrices que "enlazan" todos estos trabajos entre sí, y que le dan un sentido de unidad al volumen. Uno de estos temas transversales es el de la capacidad comunicativa y, en este sentido, el rol activo o agencia de los textiles. En otros términos, pensamos que de una u otra forma cada uno de los trabajos del dossier pone en evidencia las múltiples capas de sentido que poseen los textiles y las múltiples lecturas que de ellos se desprenden. Así, con su sola presencia estas materialidades comunican distintos tipos de mensajes acerca de etnicidad, sexualidad, disposiciones de género, jerarquías sociales, simbolismo religioso, poder, política, entre otros. $\mathrm{Y}$, entre estos 
tópicos, la identidad de los cuerpos que los portan se visualiza como otro eje de unidad, que es abordado en los trabajos desde diversas escalas: personal, de clase, grupal o comunitaria.

Varios de los ejemplos destacan asimismo la dinámica y la "plasticidad" que pueden poseer las tradiciones y las prácticas de las comunidades productoras de textiles, lo que permite que ocurran cambios que incluyen apropiaciones y resignificaciones de técnicas, instrumental, materiales (foráneos y/o "modernos"), formas y funciones de las prendas, etc., sin por ello dejar al mismo tiempo de persistir (o resistir) numerosos elementos de continuidad histórica como anclajes de memoria.

Sin más preámbulos, invitamos entonces a sumergirse en la lectura de esta serie de trabajos en los cuales la materialidad textil se despliega en su sentido más amplio, como parte constitutiva de una red dinámica de relaciones múltiples, enmarcada en contextos temporales, espaciales, sociales, económicos y políticos particulares. 
